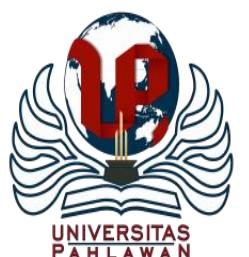

Jurnal Basicedu Volume 5 Nomor 1 Tahun 2021 Halaman 218 - 226

JURNAL BASICEDU

Research \& Learning in Elementary Education

https://jbasic.org/index.php/basicedu

\title{
Pengaruh Model Pembelajaran Think Pair Share (TPS) Terhadap Kemampuan Berpikir Kritis di Sekolah Dasar
}

\author{
Septi Fitri Meilana ${ }^{1}$, Nur Aulia ${ }^{2}$, Zulherman $^{3}$, Galih Baskoro Aji ${ }^{4}$ \\ Pendidikan Guru Sekolah Dasar, Fakultas Keguruan dan Ilmu Pendidikan, \\ Universitas Muhammadiyah Prof.DR.HAMKA ${ }^{1,2,3,4}$ \\ E-mail: $\underline{\text { septi.fitri.meilana@uhamka.ac.id }}{ }^{1}$, nurauliaa04@ gmail.com ${ }^{2}$, zulherman @uhamka.ac.id $^{3}$, \\ galih.baskoro.aji@gmail.com ${ }^{4}$
}

\begin{abstract}
Abstrak
Penelitian ini bertujuan untuk mengetahui pengaruh model pembelajaran Think Pair Share (TPS) terhadap kemampuan berpikir kritis Ilmu Pengetahuan Sosial (IPS) pada siswa kelas V SDN Bintara VI Bekasi Barat. Penelitian ini menggunakan metode quasi experimental design dengan bentuk the non equivalent post-test only control design. Sampel penelitian terdiri dari 48 siswa, kelas V-A dan V-B dengan teknik purposive sampling. Instrumen yang digunakan berupa tes subjektif esai. Uji persyaratan analisis yang digunakan untuk uji normalitas yaitu uji liliefors dan uji homogenitas menggunakan uji fisher. Untuk pengujian hipotesis menggunakan uji-T. Hasil penelitian diperoleh $\mathrm{t}_{\text {hitung }}>\mathrm{t}_{\text {tabel }}$ atau 3,117 $>2,015$, maka $\mathrm{H}_{0}$ ditolak, artinya terdapat pengaruh yang signifikan dalam pengaruh model pembelajaran Think Pair Share (TPS) terhadap kemampuan berpikir kritis Ilmu Pengetahuan Sosial (IPS) siswa kelas V SDN Bintara VI Bekasi Barat. Model belajar TPS membuktikan perubahan kemampuan berpikir siswa semakin baik dan sesuai dengan prestasi belajar yang dicapai siswa.
\end{abstract}

Kata kunci: model pembelajaran think pair share (TPS),ilmu pengetahuan sosial (IPS),kemampuan berpikir kritis

\begin{abstract}
This study aims to determine the influence of the Social Science critical thinking ability of class V SDN Bintara $V I$ West Bekasi. The study uses a quantitative approach, with the quasi experimental design method in the non equivalent posstest-only control group design research design. The sampel each of 48 students, class $V$-A and $V$-B with the purposive sampling. In this research, the instrument used is an essay subjective test. Furthermore, the data were analyzed using the requirements test, namely the normality test using the liliefors test and homogeneity test result using fisher's test. In the hypothesis test with $t$-test, was used obtained $t_{\text {count }}>t_{\text {tabel }}$ or $3,117>2,015$, thus $H_{0}$ was rejected which stated that there was a significant influence on learning by using the Think Pair Share (TPS) model on the Social Science critical thinking ability of class V SDN Bintara VI in West Bekasi. The TPS learning model proves that changes in students' thinking abilities are getting better and in accordance with the learning achievements achieved by students.
\end{abstract}

Keywords: think pair share (TPS) model, social science, critical thinking ability.

Copyright (c) 2021 Septi Fitri Meilana, Nur Aulia, Zulherman, Galih Baskoro Aji

$\triangle$ Corresponding author :

Address : FKIP UHAMKA, Pasar Rebo, Jakarta

Email : septi.fitri.meilana@uhamka.ac.id

ISSN 2580-3735 (Media Cetak)

Phone : 082311959238

ISSN 2580-1147 (Media Online)

DOI: https://doi.org/10.31004/basicedu.v5i1.644 


\section{Pengaruh Model Pembelajaran Think Pair Share (TPS) Terhadap Kemampuan Berpikir Kritis di Sekolah Dasar - Septi Fitri Meilana, Nur Aulia, Zulherman, Galih Baskoro Aji DOI: https://doi.org/10.31004/basicedu.v5i1.644}

\section{PENDAHULUAN}

Berkembangnya zaman dari tahun ke tahun semakin membawa banyak perubahan dan kemajuan di dalam kehidupan manusia, salah satunya perubahan dan kemajuan di bidang pendidikan. Pendidikan sebagai suatu proses untuk untuk membangun kecerdasan dan membentuk karakter kepribadian suatu bangsa. Education has a significant role in producing quality human resources and being able to face global competition in all aspects of life (Pulido-Martínez, 2019). Pendidikan memainkan peran penting dalam proses pembangunan bangsa, proses pada pendidikan saat ini membutuhkan pemahaman siswa yang kuat.

Ilmu Pengetahuan Sosial berasal dari social study menurut National Council For Sosial Studies (NSCC) dalam (Murni, 2017) mendefinisikan suatu studi yang terintegritas dari ilmu-ilmu sosial dan humanoira untuk meningkatkan kemampuan warga negara. Menurut (Gunawan, 2016) IPS adalah ilmu sosial yaitu suatu bahan kajian terpadu yang merupakan penyerderhanaan, adaptasi, seleksi, dan modifkasi yang diorganisasikan dari konsep-konsep dan keterampilan sejarah, geografi, sosiologi, antropologi, dan ekonomi.

Salah satu tujuan dari mempelajari IPS menurut kurikulum Depdiknas tahun 2006 dalam (Gunawan, 2016) agar siswa: (1) mengenal konsep-konsep yang berkaitan dengan kehidupan masyarakat dan lingkungannya; (2) memiliki kemampuan dasar untuk berpikir logis dan kritis, rasa ingin tahu, inquiry, memecahkan masalah dan terampil dalam kehidupan sosial masyarakat; (3) memiliki komitmen dan kesadaran terhadap nilai- nilai sosial dan kemanusiaan; (4) memiliki kemampuan berkomunikasi, bekerja sama dan berkompetisi dalam masyarakat yang majemuk, di tingkat lokal, nasional dan global.

Berpikir kritis penting untuk menyiapkan siswa dalam menghadapi berbagai persoalanpersoalan yang ada di dalam kehidupan sehari-hari (Zulfadewina et al., 2020; Zulherman et al., 2020). Salah satu peran siswa yaitu menyumbangkan solusi atau gagasan terhadap pemecahan suatu permasalahan yang sedang terjadi dalam kehidupan masyarakat (Masus \& Fadhilaturrahmi, 2020).

Berpikir kritis merupakan kemampuan kognitif seseorang untuk menyatakan sesuatu dengan penuh keyakinan karena bersumber pada alasan yang logis dan bukti yang kuat. Menurut Johson dalam (Egok, 2016) berpikir kritis merupakan sebuah proses terorganisasi yang memungkinkan siswa mengevaluasi bukti, asumsi, logika, dan bahasa yang mendasari pernyataan orang lain. Selain itu, menurut (Sari et al., 2017) berpikir kritis adalah kemampuan menyelesaikan masalah secara rasional menurut tahapan yang logis dan memberikan hasil pemecahan yang lebih efisien.

Menurut Ennis dalam (Sani, 2019), kemampuan berpikir kritis dikelompokkan menjadi 5 aspek indikator kemampuan berpikir kritis, yaitu: 1) memberikan penjelasan sederhana (meliputi: memfokuskan masalah, menganalisis argumen, bertanya dan menjawab pertanyaan klasifikasi atau pertanyaan yang menantang), 2) membangun keterampilan dasar (meliputi mempertimbangkan kredibilitas suatu sumber, mengobservasi dan 


\section{Pengaruh Model Pembelajaran Think Pair Share (TPS) Terhadap Kemampuan Berpikir Kritis di Sekolah Dasar - Septi Fitri Meilana, Nur Aulia, Zulherman, Galih Baskoro Aji DOI: https://doi.org/10.31004/basicedu.v5i1.644}

mempertimbangkan hasil observasi), 3) melakukan inferensi (meliputi membuat deduksi dan mempertimbangkan hasil deduksi, membuat keputusan dan mempertimbangkan hasilnya), 4) memberikan penjelasan lebih lanjut (meliputi mendefinisikan istilah dan mempertimbangkan definisi, mengidentifikasi asumsi), 5) mengatur strategi dan teknik (meliputi merumuskan dan memutuskan suatu tindakan, menyampaikan argumen secara lisan maupun tulisan).

Fakta yang ditemukan di lapangan saat pembelajaran IPS, pada saat guru memberikan kesempatan bagi siswa untuk bertanya mengenai materi pembelajaran, siswa cenderung pasif dan tidak mau bertanya, namun ketika guru memberikan pertanyaan kepada siswa, mereka hanya menjawab pertanyaan tersebut dengan jawaban yang sudah tertera di dalam buku. Hal ini disebabkan karena siswa hanya menghapal jawaban dan belum mampu menemukan terkaitan hubungan antara materi yang dipelajari dengan kehidupan sehari-hari.

Kegiatan pembelajaran IPS di sekolah masih saja berpusat pada guru (teacher center) sebagai pemberi informasi, guru kurang memberikan kegiatan pada siswa selama pembelajaran berlangsung untuk melakukan kegiatan berpikir dalam memecahkan suatu masalah karena guru hanya terfokus pada pedoman buku saja. Guru juga belum tepat dalam memilih model pembelajaran yang sesuai dengan materi yang disampaikan sehingga siswa belum dapat memahami materi yang dipelajari dengan baik.

Hal ini menyebabkan belum berkembangnya kemampuan berpikir kritis siswa selama proses pembelajaran berlangsung. Hal ini berdampak pada saat hasil ulangan harian IPS, banyak dari siswa yang belum memenuhi standar Kriteria Ketuntasan Minimal (KKM) yang telah ditentukan oleh sekolah dan siswa masih banyak yang belum memahami materi yang dipelajari dengan baik.

Cooperative learning is one of the teaching methods that was consciously involving the learners (Avc1 et al., 2019). Pembelajaran kooperatif adalah suatu metode yang digunakan secara sadar yang melibatkan langsung dengan peserta didik. Pada pembelajaran kooperatif beragam jenis modelnya, salah satunya adalah model Think Pair Share (TPS).

"Collaborative and cooperative learning have many similarities. The notion that the role of the teacher in guiding either cooperative or collaborative learning is similar is particularly relevant to this review: he or she is seen as a facilitator to guide student groups" (van Leeuwen \& Janssen, 2019).

Model pembelajaran TPS terdiri dari tahap thinking, dimana guru memberikan pertanyaan atau permasalahan terhadap siswa. Tahap tersebut siswa diberi waktu berpikir sendiri terlebih dahulu. Selanjutnya tahap pairing, siswa bersama pasangannya berdiskusi mengenai jawaban yang didapatkannya pada tahap thinking. Kemudian tahap sharing, dimana siswa membagikan hasil jawaban mereka ke depan kelas.

Menurut (Kurniasih \& Sani, 2015) menyatakan bahwa model pembelajaran Think Pair Share (TPS) atau berpikir berpasangan dan berbagi merupakan pembelajaran kooperatif yang dirancang untuk mempengaruhi pola interaksi siswa di sekolah. Model ini dirancang untuk mempengaruhi proses interaksi siswa selama 
kegiatan pembelajaran berlangsung. Selain itu, menurut (Wicaksono et al., 2017) menyatakan model Think Pair Share (TPS) merupakan model pembelajaran yang memberikan kesempatan bagi siswa untuk lebih leluasa dalam merespons pengetahuan maupun soal yang diberikan.

Berdasarkan uraian diatas, dengan adanya penggunaan model pembelajaran Think Pair Share (TPS) diharapkan mampu meningkatkan kemampuan berpikir kritis siswa. Oleh karena itu, untuk mengetahui ada atau tidaknya pengaruh model pembelajaran TPS terhadap kemampuan berpikir kritis perlu dilakukan penelitian yang berjudul "Pengaruh model pembelajaran Think Pair Share (TPS) terhadap kemampuan berpikir kritis IPS siswa kelas V SDN Bintara VI Bekasi Barat".

\section{METODE}

Penelitian ini termasuk dalam penelitian eksperimen quasi eksperimental design dengan desain the non equivalent post-test only control design. Desain penelitian ini menggunakan dua kelompok yaitu kelompok eksperimen dan kelompok kontrol. Kelompok eksperimen diberi perlakuan dengan penerapan model TPS, sedangkan kelompok kontrol hanya diberikan perlakuan dengan model konvensional. Penelitian ini dilaksanakan pada semester II tahun ajaran 2019/2020 di SDN Bintara VI Bekasi Barat.

Populasi dalam penelitian ini adalah seluruh siswa kelas V SDN Bintara VI Bekasi Barat tahun ajaran 2019/2020 sebanyak tiga kelas. Sampel dalam penelitian ini terdiri dari dua kelas, yaitu kelas V-A sebagai kelas kontrol dengan jumlah 24 siswa dan kelas V-C sebagai kelas eksperimen dengan jumlah 24 siswa. Teknik pengambilan sampel yang digunakan pada penelitian ini adalah non probability sampling, yaitu teknik pengambilan sampel yang tidak memberi peluang atau kesempatan sama bagi setiap unsur atau anggota sampel untuk dipilih menjadi sampel. Sampel yang diambil sebanyak dua kelas secara sengaja dengan pertimbangan tertentu. Variabel bebas dalam penelitian ini adalah model pembelajaran Think Pair Share (TPS) sedangkan variabel terikatnya adalah kemampuan berpikir kritis IPS. Instrumen penelitian dilakukan uji validasi isi dan instrumen. Uji validasi isi dan instrumen juga divalidasi konstruk oleh ahli (judgment expert).

Prosedur penelitian dalam penelitian ini menyesuaikan dengan pembelajaran yang berlangsung saat ini secara daring dengan berbantu platform whattsapp group. Guru membuat grup kelompok kecil untuk setiap anggota kelompoknya berdikusi sebelum menjelaskan hasil diskusinya dengan kelompok ke grup kelas. Teknik pengumpulan data menggunakan teknik tes berdasarkan hasil post-test setelah kedua kelas diberikan perlakuan masing-masing berupa soal essay untuk mengukur kemampuan berpikir kritis IPS siswa.

Analisis data pada penelitian ini yaitu teknik analisis dengan uji perbedaan data rata-rata populasi menggunakan uji-t ( $t$-test) dengan taraf signifikan 0,05 atau $5 \%$.

Uji persyaratan harus dilakukan sebelum uji hipotesis, diantaranya dilakukan uji normalitas dan uji homogenitas. Uji normalitas yang digunakan 


\section{Pengaruh Model Pembelajaran Think Pair Share (TPS) Terhadap Kemampuan Berpikir Kritis}

di Sekolah Dasar - Septi Fitri Meilana, Nur Aulia, Zulherman, Galih Baskoro Aji

DOI: https://doi.org/10.31004/basicedu.v5i1.644

dalam penelitian ini yaitu uji liliefors, sedangkan uji homogenitas yaitu uji fisher atau uji-F. Uji ini dilakukan dengan taraf signifikan 0,05 .

\section{HASIL DAN PEMBAHASAN}

Berdasarkan perhitungan uji validitas, butir soal yang dinyatakan valid apabila $r_{\text {hitung }}$ lebih besar atau sama dengan $r_{\text {tabel }}\left(r_{\text {hitung }}>r_{\text {tabel }}\right)$. Dari 11 soal esai yang diuji cobakan, hasil yang di peroleh yaitu 9 soal yang valid dan 2 soal tidak valid. Lalu 9 soal yang valid ini akan digunakan peneliti sebagai instrumen untuk mengukur kemampuan berpikir kritis IPS siswa dalam penelitian.

Tabel 1 Klasifikasi Butir Soal Validitas

\begin{tabular}{|c|c|c|}
\hline Kategori & $\begin{array}{c}\text { Jumlah Item } \\
\text { Soal }\end{array}$ & $\begin{array}{c}\text { Nomor Soal } \\
\text { Valid }\end{array}$ \\
\hline Valid & 9 & $\begin{array}{c}1,2,4,5,7,8,9, \\
10,11\end{array}$ \\
\hline Tidak Valid & 2 & 3,6 \\
\hline
\end{tabular}

Kemudian dalam perhitungan reliabilitas rumus yang digunakan dalam penelitian untuk menghitung reliabilitas instrumen, yaitu menggunakan rumus alpha cronbach dengan taraf signifikan $\alpha=0,05$. Uji reliabilitas dilakukan dengan tujuan untuk mengetahui tingkat kesamaan dari soal-soal yang valid. Data dapat dinyatakan reliabel apabila $\mathrm{r}_{\text {hitung }}$ lebih besar dari $\mathrm{r}_{\text {tabel }}\left(\mathrm{r}_{\text {hitung }}>\right.$ $\mathrm{r}_{\text {tabel }}$ ), maka data tersebut dapat dinyatakan reliabel. Berikut hasil data perhitungan.

Tabel 2 Hasil Perhitungan Uji Reliabilitas

\begin{tabular}{|c|c|c|c|c|}
\hline $\begin{array}{c}\text { Taraf } \\
\text { Signifikan }\end{array}$ & $\mathbf{n}$ & $\mathbf{r}_{\text {hitung }}$ & $\mathbf{r}_{\text {tabel }}$ & Keterangan \\
\hline 0,05 & 29 & 0,661 & 0,367 & Reliabel \\
\hline
\end{tabular}

Dari perhitungan reliabilitas dengan menggunakan rumus alpha cronbach, diperoleh $r_{\text {hitung }} 0,061$ dibandingkan dengan $r_{\text {tabel }}$ dengan $\alpha=$ 0,05 dan $\mathrm{n}=29$ yaitu 0,367 , sehingga diperoleh $r_{\text {hitung }}>r_{\text {tabel }}(0,661>0,367)$ maka data tersebut dinyatakan reliabel dan layak untuk digunakan sebagai instrumen penilaian dalam penelitian.

Berdasarkan hasil data yang diperoleh setelah memberikan perlakuan kepada kelas eksperimen dan kelas kontrol, maka rata-rata nilai siswa yang mengerjakan soal post-test sebagai berikut:

Tabel 3 Perbandingan Rata-rata Nilai Post-test

\begin{tabular}{|l|l|l|}
\hline \multicolumn{1}{|c|}{ Keterangan } & $\begin{array}{c}\text { Kelas } \\
\text { Ekperimen }\end{array}$ & Kelas Kontrol \\
\hline $\begin{array}{l}\text { Skor } \\
\text { Maksimum }\end{array}$ & 97 & 56 \\
\hline Skor Minimum & 92 & 47 \\
\hline Rata-Rata & 81,42 & 70,79 \\
\hline Median & 83,5 & 73,16 \\
\hline Modus & 87 & 74,86 \\
\hline
\end{tabular}

Terdapat perbedaan hasil jawaban soal posttest siswa kelas eksperimen dan kelas kontrol, yaitu kelas eksperimen memperoleh nilai rata-rata 81,42 sedangkan kelas kontrol memperoleh nilai rata-rata 70,79. Untuk melengkapi pengujian hipotesis maka dilakukan beberapa pengujian antara lain: (1) uji normalitas dengan menggunakan uji liliefors, dan (2) uji homogenitas menggunakan uji fisher.

Berdasarkan hasil uji normalitas menggunakan rumus uji liliefors diperoleh harga $\mathrm{L}_{\text {hitung }}$ lebih kecil dari $\mathrm{L}_{\text {tabel }}(0,080<0,121)$ ini berarti sampel tersebut berdistribusi normal dengan hasil perhitungan sebagai berikut : 

di Sekolah Dasar - Septi Fitri Meilana, Nur Aulia, Zulherman, Galih Baskoro Aji DOI: https://doi.org/10.31004/basicedu.v5i1.644

Tabel 4 Hasil Perhitungan Uji Normalitas

\begin{tabular}{|l|l|l|c|l|}
\hline \multicolumn{1}{|c|}{ Kelas } & \multicolumn{1}{|c|}{ Lhitung } & Ltabel & $\begin{array}{c}\text { Krite } \\
\text { ria }\end{array}$ & $\begin{array}{c}\text { Keteran } \\
\text { gan }\end{array}$ \\
\hline Eksperimen & 0,080 & \multirow{2}{*}{0,173} & $\begin{array}{c}\text { Lhitung } \\
\leq \\
\text { L }_{\text {tabel }}\end{array}$ & $\begin{array}{l}\text { Data } \\
\text { berdistri } \\
\text { busi } \\
\text { normal }\end{array}$ \\
\hline Kontrol & 0,121 & &
\end{tabular}

Berdasarkan hasil perhitungan pada tabel di atas, maka dapat disimpulkan bahwa uji normalitas dari hasil post-test yang digunakan dalam penelitian memperoleh hasil yaitu $\mathrm{L}_{\text {hitung }}$ lebih kecil dari $\mathrm{L}_{\text {tabel }}$ maka kedua sampel tersebut dikatakan berdistribusi normal.

Kemudian dalam uji homogenitas menggunakan rumus uji fisher. Hasil perhitungan uji homogenitas tersebut dapat dilihat pada table di bawah ini:

Tabel 5 Hasil Perhitungan Uji Homogenitas

\begin{tabular}{|l|c|c|c|l|l|}
\hline Kelas & $\begin{array}{c}\text { Varian } \\
\text { s }\end{array}$ & $\begin{array}{c}\mathbf{F}_{\text {hi }} \\
\text { tung }\end{array}$ & $\begin{array}{c}\mathbf{F}_{\text {tab }} \\
\text { el }\end{array}$ & $\begin{array}{c}\text { Kriteri } \\
\text { a }\end{array}$ & $\begin{array}{l}\text { Ketera } \\
\text { ngan }\end{array}$ \\
\hline $\begin{array}{l}\text { Eksperi } \\
\text { men }\end{array}$ & 108,080 & $\begin{array}{l}1,5 \\
85\end{array}$ & $\begin{array}{l}2,0 \\
1\end{array}$ & $\begin{array}{l}F_{\text {hitung }} \leq \\
\mathrm{F}_{\text {tabel }}\end{array}$ & $\begin{array}{l}\text { Data } \\
\text { bersifat } \\
\text { homog } \\
\text { en }\end{array}$ \\
\hline Kontrol & 171,303 & & \\
\hline
\end{tabular}

Berdasarkan hasil perhitungan tabel diatas, hasil kemampuan berpikir kritis IPS siswa kelas V memiliki hasil varians terbesar kelas kontrol dan varians terkecil kelas eksperimen. Kemudian varian terbesar (171,303) dibagi varian terkecil $(108,080)$ yaitu 1,585 . Jadi dapat disimpulkan dari kedua kelas tersebut bersifat homogen.

Uji hipotesis digunakan untuk mengetahui adanya pengaruh terhadap penggunaan model pembelajaran Think Pair Share (TPS) terhadap kemampuan berpikir kritis IPS siswa kelas V di SDN Bintara VI Bekasi Barat. Dalam perhitungan uji hipotesis menggunakan rumus uji-t untuk dianalisis. Hasil perhitungan uji-t dapat dilihat pada tabel di bawah ini.

Tabel 6 Hasil Perhitungan Uji Hipotesis

\begin{tabular}{|l|l|l|l|l|l|}
\hline Kelas & $\begin{array}{l}\text { Rata- } \\
\text { rata }\end{array}$ & $\begin{array}{l}\mathbf{D} \\
\mathbf{k}\end{array}$ & $\begin{array}{l}\mathbf{T}_{\text {hitun }} \\
\mathbf{g}\end{array}$ & $\mathbf{T}_{\text {tabel }}$ & $\begin{array}{l}\text { Keteranga } \\
\mathbf{n}\end{array}$ \\
\hline $\begin{array}{l}\text { Eksperime } \\
\text { n }\end{array}$ & 81,42 & $\begin{array}{l}4 \\
6\end{array}$ & 3,117 & $\begin{array}{l}2,01 \\
5\end{array}$ & $\begin{array}{l}\text { Terdapat } \\
\text { pengaruh } \\
\text { signifikan }\end{array}$ \\
\hline Kontrol & 70,79 & & & &
\end{tabular}

Berdasarkan perhitungan pengujian uji hipotesis dengan uji-t pada taraf signifikan $\alpha=0,05$ dengan $\mathrm{dk}=46$ maka hasil $\mathrm{t}_{\text {hitung }}(3,117)>\mathrm{t}_{\text {tabel }}$ $(2,015)$ maka dapat disimpulkan bahwa nilai ratarata hasil post-test kemampuan berpikir kritis IPS siswa kelas eksperimen lebih tinggi dibanding nilai kelas kontrol. Maka $\mathrm{H}_{1}$ diterima dan $\mathrm{H}_{\mathrm{o}}$ ditolak dengan berarti ada pengaruh yang signifikan penggunaan model pembelajaran Think Pair Share (TPS) terhadap kemampuan berpikir kritis IPS siswa kelas V SDN Bintara VI Bekasi Barat.

Berdasarkan penelitian sebelumnya oleh (Puspitasari et al., 2016) bahwa TPS mampu meningkatkan memotivasi dan nilai belajar siswa selain kemampuan berpikir kritis dalam menerima materi pelajaran, hal ini dilihat aspek peningkatan nilai prestasi belajar siswa. Dalam penelitian lainnya oleh (Reinita \& Andriska, 2017) bahwa model TPS juga memberikan kesan kebersamaan dalam belajar (kooperatif) karena siswa saling melengkapi, jika ada kesalahan dan kekurangan dalam menerima pelajaran. Pada penelitian lainnya oleh (Yoserizal \& Rahmi, 2019) menunjukkan bahwa model TPS melatih siswa untuk meningkatkan rasa percaya diri dan berdiskusi dengan teman. Dalam penelitian oleh (Sariayu \& Miaz, 2020) juga menemukan bahwa model TPS 


\section{Pengaruh Model Pembelajaran Think Pair Share (TPS) Terhadap Kemampuan Berpikir Kritis di Sekolah Dasar - Septi Fitri Meilana, Nur Aulia, Zulherman, Galih Baskoro Aji DOI: https://doi.org/10.31004/basicedu.v5i1.644}

dalam aktivitas belajarnya sangat membantu siswa dalam meningkatkan rasa percaya diri dan berani berdiskusi di kelas. Lalu penelitian oleh (Perwita \& Indrawati, 2020)juga menunjukkan hal yang sama yaitu model TPS mampu meningkatkan proses berpikir siswa dalam pembelajaran tematik.

\section{SIMPULAN}

Simpulan dari penelitian ini adalah sebagai berikut: (1) Hasil perhitungan validitas pada 11 butir soal berupa soal esai dengan menggunakan rumus product moment yang terhitung, didapatkan 9 butir soal valid. Masing-masing butir soal yang telah dinyatakan valid karena $r_{\text {hitung }} \geq r_{\text {tabel. }}$. (2) Selanjutnya perhitungan reliabilitas dengan menggunakan rumus alpha cornbach yang diperoleh $r_{\text {hitung }}=0,661$. Maka butir soal yang telah valid sebanyak 9 soal dinyatakan reliabel karena $r_{\text {hitung }} \geq r_{\text {tabel }}$ yaitu $0,661 \geq 0,367$. (3) Hasil perhitungan kemampuan berpikir kritis IPS di kelas eksperimen dengan menggunakan model pembelajaran Think Pair Share (TPS) untuk nilai rata-rata 81,42 ; varians sebesar 108,080 dan simpangan baku 10,396. Sedangkan hasil perhitungan kemampuan berpikir kritis IPS di kelas kontrol dengan menggunakan model konvensional untuk rata-rata sebesar 70,79; varians sebesar 171,303 dan simpangan baku sebesar 13,088. (4) Uji normalitas pada penelitian ini menggunakan uji liliefors diperoleh $\mathrm{L}_{\text {hitung }}$ kelas eksperimen sebesar 0,080 dan nilai $L_{\text {hitung }}$ kelas kontrol 0,121. Pada penelitian ini menggunakan taraf signifikan $a=0,05$ dengan $n=24$ dan $n=24$ nilai $\mathrm{L}_{\text {tabel }}$ masing-masing sebesar 0,173 , maka $\mathrm{H}_{0}$ diterima dapat dinyatakan bahwa kedua sampel tersebut berdistribusi normal. (5) Dari hasil uji homogenitas menggunakan uji fisher diperoleh derajat kebebasan pembilang 23 dan penyebut 23, sehingga didapati $F_{\text {hitung }}$ sebesar 1,585 dan $F_{\text {tabel }}$ sebesar 2,01. Berdasarkan kriteria penguji yaitu $F_{\text {hitung }} \leq \mathrm{F}_{\text {tabel }}$ berarti $\mathrm{H}_{0}$ diterima maka bersifat homogen. (6) Setelah pengujian normalitas dan homogenitas, dilanjutkan dengan uji hipotesis menggunakan uji-t yang diperoleh hasil $t_{\text {hitung }}$ sebesar 3,117 dan $t_{\text {tabel }}$ sebesar 2,015. Karena thitung $\geq t_{\text {tabel }}$ maka $\mathrm{H}_{0}$ ditolak dan $\mathrm{H}_{1}$ diterima artinya terdapat pengaruh kemampuan berpikir kritis IPS siswa kelas V SDN Bintara VI dengan menerapkan model pembelajaran Think Pair Share (TPS). Artinya berdasarkan hasil penelitian tentang pengaruh model pembelajaran Think Pair Share (TPS) terhadap kemampuan berpikir kritis IPS siswa dapat disimpulkan bahwa model Think Pair Share (TPS) berpengaruh terhadap kemampuan berpikir kritis siswa kelas V SDN Bintara VI Bekasi Barat.

\section{Saran}

Berdasarkan hasil penelitian yang diperoleh, maka peneliti memberikan beberapa saran sebagai berikut: (1) Bagi guru, guru hendaknya berinovasi dalam memilih model pembelajaran yang sesuai dengan tujuan dan materi yang akan diajarkan, dengan begitu proses pembelajaran akan berlangsung menyenangkan salah satunya dengan menggunakan model pembelajaran Think Pair Share (TPS). (2) Bagi kepala sekolah, diharapkan memberikan dukungan dan peluang kepada guru untuk menciptakan proses pembelajaran yang berinovasi dengan memberikan pelatihan dan 

di Sekolah Dasar - Septi Fitri Meilana, Nur Aulia, Zulherman, Galih Baskoro Aji DOI: https://doi.org/10.31004/basicedu.v5i1.644

workshop sebagai bekal guru dalam mencapai tujuan pendidikan serta menghasilkan siswa yang berprestasi. (3) Bagi peneliti selanjutnya, diharapkan untuk peneliti selanjutnya, harus mempersiapkan waktu yang tepat dalam proses pembelajaran. Hal ini dilakukan agar pembagian waktu setiap kegiatan belajar tidak kehabisan waktu. Selain itu, referensi yang digunakan peneliti masih kurang, oleh karena itu, harap lebih dilengkapi lagi untuk penelitian selanjutnya.

\section{DAFTAR PUSTAKA}

Avcı, F., Kırbaşlar, F. G., \& Şeşen, B. A. (2019). Instructional curriculum based on cooperative learning related to the structure of matter and its properties: Learning achievement, motivation and attitude. South African Journal of Education, 39(3).

Egok, A. S. (2016). Kemampuan Berpikir Kritis Dan Kemandirian Belajar Dengan Hasil Belajar Matematika. Jurnal Pendidikan Dasar, 7(2), 186.

Gunawan, R. (2016). PENDIDIKAN IPS. ALFABETA. https://doi.org/10.1055/s-20081040325

Kurniasih, I., \& Sani, B. (2015). RAGAM PENGEMBANGAN MODEL PEMBELAJARAN. Kata Pena. https://doi.org/10.1055/s-2008-1040325

Masus, S. B., \& Fadhilaturrahmi, F. (2020). PENINGKATAN KETERAMPILAN PROSES SAINS IPA DENGAN MENGGUNAKAN METODE EKSPERIMEN DI SEKOLAH DASAR. Jurnal Pendidikan Dan Konseling (JPDK), 2(1), 46-55.

Murni, W. (2017). Metodologi Pembelajaran IPS Pengembangan Standar Proses Pembelajaran IPS di Sekolah/Madrasah. Yogyakarta: Ar-Ruzz Media.

Perwita, L. W., \& Indrawati, T. (2020). Peningkatan Proses Pembelajaran Tematik Terpadu Menggunakan Model Cooperative
Learning Tipe Talking Stick di SD. ... Pembelajaran Inovasi, Jurnal Ilmiah ..., 4, 2624-2636.

http://ejournal.unp.ac.id/students/index.php/p gsd/article/view/9511

Pulido-Martínez, H. C. (2019). Analysing the artefacts to produce an education of quality: from the disciple to the customer in a Colombian university. Subjectivity. https://doi.org/10.1057/s41286-019-00081-w

Puspitasari, E., Setyosari, P., \& Amirudin, A. (2016). Peningkatan motivasi dan hasil belajar melalui think pair share (tps) di sekolah dasar. Jurnal Pendidikan: Teori, Penelitian, Dan Pengembangan, 1(7), 14321436.

Reinita, R., \& Andriska, D. (2017). Pengaruh Pengunaan Model Kooperatif Tipe Think Pair Share (TPS) dalam Pembelajaran PKn di Sekolah Dasar. Jurnal Inovasi Pendidikan Dan Pembelajaran Sekolah Dasar, 1(2), 6173.

Sani, R. A. (2019). Pembelajaran Berbasis HOTS Edisi Revisi: Higher Order Thinking Skills (Vol. 1). Tira Smart.

Sari, N. P., Budijanto, B., \& Amiruddin, A. (2017). Pengaruh Penerapan Model Pembelajaran Problem Based Learning Dipadu Numbered Heads Together terhadap Keterampilan Metakognitif dan Kemampuan Berpikir Kritis Geografi Siswa SMA. Jurnal Pendidikan: Teori, Penelitian, Dan Pengembangan, 2(3), 440-447.

Sariayu, M. R., \& Miaz, Y. (2020). Peningkatan Aktivitas Belajar Siswa Melalui Model Think Pair Share di Sekolah Dasar. Jurnal Basicedu, 4(2), 295-305. https://doi.org/10.31004/basicedu.v4i2.337

van Leeuwen, A., \& Janssen, J. (2019). A systematic review of teacher guidance during collaborative learning in primary and secondary education. Educational Research Review, 27(February), 71-89. https://doi.org/10.1016/j.edurev.2019.02.001

Wicaksono, B., Sagita, L., \& Nugroho, W. (2017). Model Pembelajaran Group Investigation (GI) dan Think Pair Share (TPS) terhadap Kemampuan Berpikir Kritis. AKSIOMA: Jurnal Matematika Dan Pendidikan 
226 Pengaruh Model Pembelajaran Think Pair Share (TPS) Terhadap Kemampuan Berpikir Kritis di Sekolah Dasar - Septi Fitri Meilana, Nur Aulia, Zulherman, Galih Baskoro Aji DOI: https://doi.org/10.31004/basicedu.v5i1.644

Matematika, 8(2), 1-8.

Yoserizal, Y., \& Rahmi, U. (2019). PERBEDAAN

AKTIVITAS BELAJAR SISWA

TERHADAP MODEL COOPERATIVE

LEARNING TIPE SNOWBALL

THROWING DAN TIPE THINK PAIR

SHARE DI SEKOLAH DASAR. Jurnal Basicedu, 3(4), 1055-1064.

Zulfadewina, Sucipto, A., Iba, K., \& Zulherman. (2020). Jurnal basicedu. Jurnal Basicedu, 4(4), 1308-1314. https://jbasic.org/index.php/basicedu\%0ADe velopment

Zulherman, Arifudin, R., \& Pratiwi, M. S. (2020). Jurnal basicedu. Jurnal Basicedu, 4(4), 1267-1273.

https://jbasic.org/index.php/basicedu 